\title{
Malignant melanoma at the hard palate and gingiva: a rare localization
}

\section{Damakta ve gingivada malin melanom: Nadir bir lokalizasyon}

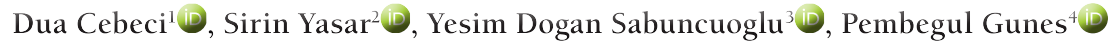 \\ ${ }^{1}$ Dept of Dermatology and Venereology, Famagusta State Hospital, Famagusta, Northern Cyprus, ${ }^{2}$ Dept of Dermatology and Venereology, \\ Haydarpasa Numune Training And Research Hospital, Istanbul, Turkey, ${ }^{3}$ Dept of Dermatology and Venereology, Beykoz State Hospital, Istanbul, \\ Turkey, ${ }^{4}$ Dept of Pathology, Haydarpasa Numune Training And Research Hospital, Istanbul, Turkey
}

\begin{abstract}
Primary malignant melanoma is a rare and aggressive neoplasm that originates from the proliferation of melanocytes. Oral mucosal melanoma is a rare malignancy that tends to metastasize and to invade tissues more easily than other malignant tumors of the oral cavity. These tumors can be found anywhere in the oral cavity; however, they affect the hard palate and maxillary alveolar mucosa more frequently. Most mucosal melanomas are like chameleons and may be confused with many melanocytic lesions. In general, they are asymptomatic in the early stages and are presented as a mass that delays diagnosis until signs of a pigmented patch or swelling, ulceration, bleeding, or loosening of the teeth. In this article, we present a case of malignant melanoma of the maxillary anterior gingiva in a 79-year-old female patient. Immunohistochemistry and special staining were performed to confirm the diagnosis histopathologicaly.
\end{abstract}

Key words: mucosal melanoma, pigmented lesions, oral cavity

Özet

Primer malin melanom, melanositlerin çoğalmasından kaynaklanan nadir ve agresif bir neoplazmdır. Oral mukozal melanom, dokuları ağız boşluğunun diğer malin tümörlerinden daha kolay metastaz yapma ve istila etme eğiliminde olan nadir bir malinitedir. Bu tümörler ağız boşluğunun herhangi bir yerinde bulunmakta; bununla birlikte sert damak ve maksiller alveoler mukozayı daha sık etkilemektedir. Mukozal melanomların çoğu, bukalemun gibidir ve birçok melanositik lezyonla karışabilir. Genellikle erken evrelerde asemptomatiktirler ve pigmentli bir yama veya şişlik, ülserasyon, kanama veya dişlerin kaybı gibi belirtilerle, tanıyı geciktiren bir kitle olarak ortaya çıkarlar. Bu makalede 79 yaşında kadın hastada maksiller ön gingivada yerleşim gösteren oral malin melanom olgusunu sunuyoruz. Histopatolojik olarak tanıyı doğrulamak için imünohistokimya ve özel boyalar yapıldı.

Anahtar kelimeler: mukozal melanom, pigmentli lezyonlar, ă̆ız boşluğu

Corresponding author: Dua Cebeci, Dept. of Dermatology and Venereology, Famagusta State Hospital, Famagusta, Northern Cyprus Phone:00 90548 8586367, E-mail: perolidua@gmail.com

Received: 20 April 2020 Accepted: 26 May 2020

Conflicts of Interest: None

Funding: None

How to cite this article: Cebeci D, Yasar S, Dogan Sabuncuoglu Y, Gunes P. Malignant melanoma at the hard palate and gingiva: a rare localization. Mucosa 2020;3:52-56

(c) (i) This work is licensed under a Creative Commons Attribution-NonCommercial 4.0 International License. 


\section{Introduction}

Primary malignant melanoma in the mouth is an extremely rare tumor caused by uncontrolled growth of melanocytes in the basal layer of the oral mucous membrane. ${ }^{1}$ It is less than $1 \%$ of all melanomas, $1.6 \%$ of head and neck malignancies, and $0.6 \%$ of oral malignancies. ${ }^{2}$ Due to the delay in diagnosis, tumors are usually diagnosed at a deeper and advanced stage. ${ }^{3}$ The etiology of oral malignant melanoma is not known. In some views, nevi are considered a potential source of some oral melanomas, but this is not fully well understood. Today, most melanomas are thought to have appeared in de novo. Inhaled and ingested carcinogens such as tobacco use and chronic irritation from ill-fitting dentures are the other suggestion in the pathogenesis of oral melanoma, however a direct relation is not proved. ${ }^{1-4}$ Excisional or incisional biopsy is the gold standard for the diagnosis. Whether the lesion is a secondary tumor from the primary malignant or latent cutaneous lesion may affect the treatment and outcomes in this stage. ${ }^{5}$ The purpose of this article is to describe the nature of mucosal melanomas with the related literature and to make clinicians aware about the importance of the early diagnosis to improve the poor diagnosis of this entity.

\section{Case report}

A seventy-nine-year-old female patient applied to the department of dermatology with a complaint of the rapidly growing asymptomatic mass in gingiva for one month. Dermatological examination showed brownishgray patches with black and red discolorations, starting from the vestibular mucosa of the right maxillary gingiva and extending to the left maxillary gingiva, settling in the hard palate and upper lip mucosa. Painless and soft consistency pink tumoral lesion was observed on palpation (Fig. la-b). A solitary submandibular lymph node was also palpable in the right side about $2 \times 2 \mathrm{~cm}$ in size, which was freely mobile. Complete blood cell count and biochemistry results were within normal limits. For a confirmatory diagnosis, an incisional biopsy was performed under local anesthesia. Histopathological examination revealed infiltration of

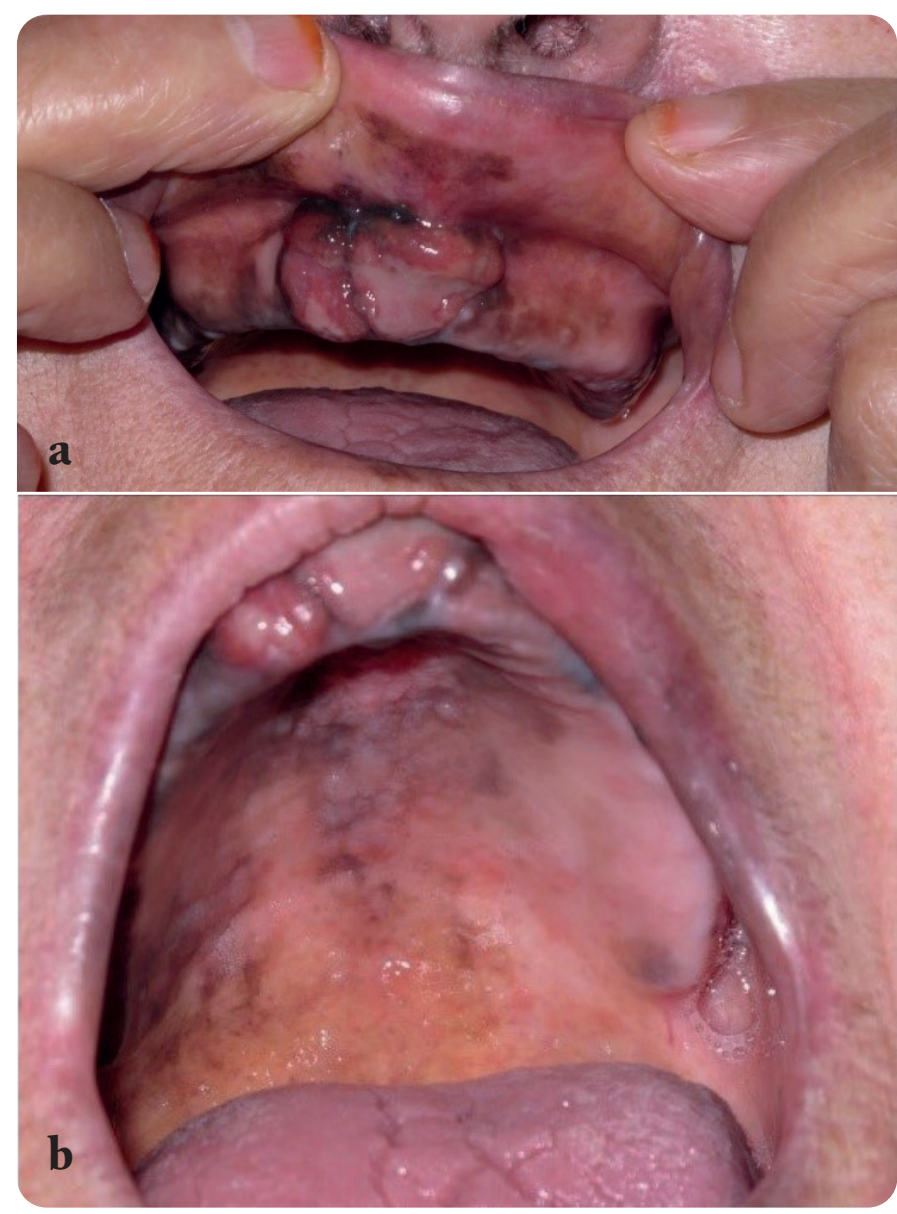

Fig. 1a-b. Brownish-gray patches with black and red discolorations and tumoral mass of the malignant melanoma in the upper gyngival region of the patient

atypical melanocytes singly and in nests, in a pagetoid and organoid fashion. Atypia and pleomorphism were observed in proliferating melanocytes extending deep into the submucosa. Immunohistochemical staining was positive for Melan-A and HMB45 (Fig. 2a-d). The patient was diagnosed as mucosal malignant melanoma with clinical and histopathological findings. Patient refused other investigations therefore advanced examination and treatment could not be performed.

\section{Discussion}

The first cases of oral melanoma were reported in 1885. $80 \%$ of oral malignant melanomas usually develop on the mucous membrane of the upper jaw (upper palate and anterior gingiva). ${ }^{4}$ Oral mucosal melanoma is asymptomatic by its nature, 


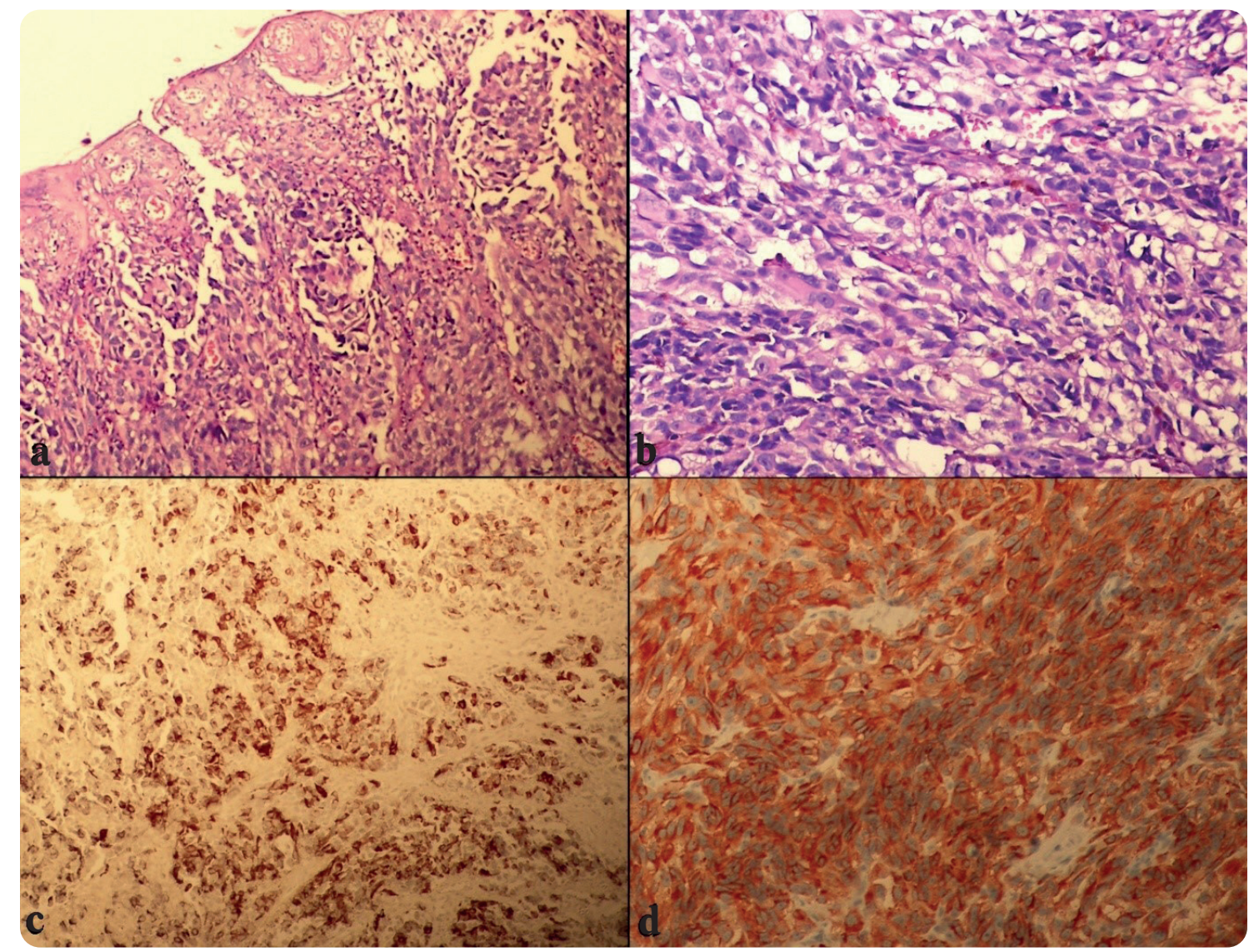

Fig. 2a-b. Proliferation consisting of atypical melanocytes in ulceration and nests in the epithelium. (H\&E x100, x200), 2c. Staining in atypical melanoma cells with HMB-45 (x200), 2d. Positive staining with Melan-A (MART) (x400)

and therefore its progression may not be noticed by patients that cause delay in diagnosis. ${ }^{6}$ The most common location is the palate and maxillary gum followed by mandibular gingiva, buccal mucosa, tongue and floor of the mouth. It is seen in adults between the ages of 55 and 65 , and usually in the males. ${ }^{7}$ Melanoma can manifest itself in the form of growth or swelling with a smooth intact or ulcerated mucosa. Oral melanoma shows color variations that can range from black, brown, gray, purple, and can also show red tones or be depigmented. ${ }^{8}$ In our case, asymptomatic swelling of grayish black color with a smooth and sessile surface and well-defined borders was detected.

Histologically, it demonstrates atypical melanocytes (nuclear pleomorphism and hyperchroma- tism), high melanocyte density in the epithelial and connective tissue junction in the biopsy. ${ }^{9}$ More than $95 \%$ of lesions are anti S-100 antigen positive, and include specific markers HMB45, Melan- $\mathrm{A}$, and anti-tyrosinase. Melan- $\mathrm{A}$, tyrosinase and vimentin are usually helpful for confirmation, especially in atypically presented pigmented melanomas.

Although different clinical and histological classification systems have been proposed, there are no accepted criteria worldwide. Therefore, Lopez et al. classified the melanoma of the oral cavity by depending on its clinical presentation: 1) pigmented nodular type, 2) pigmentless nodular type, 3) pigmented macular type, 4) pigmented mixed type and 5) pigmentless mixed type. Therefore, based 
on the histopathological model of the tumor, the classification of the Western Oral Pathology Teachers Association (WESTOP) is used follows as: (a) melanoma in situ, limited to the epidermis and its interface with the connective tissue; (b) invasive melanomas, invase into the connective tissue, and (c) melanomas with a combined pattern between invasive and in situ. Lymph nodes, central nervous system, lungs and liver are also common areas for metastasis. In end-stage patients, metastasis are observed in the local lymph nodes and in the bone. ${ }^{10}$

Differential diagnosis of melanoma are oral melanotic macula, cigarette-related melanosis, drug-related melanosis (antimalarial drugs and minocycline), melanoplakia, Cushing's syndrome, postinflammatory pigmentation, melanotic nevi, blue nevus, Addison's disease, Peutz-Jeghers syndrome, Kaposi's sarcoma. Other physiological pigmentations, that share the same macroscopic characters are melanoplakia which literally means "black plate" and physiological pigmentation that usually shows the activity of melanocytes rather than increased proliferation. ${ }^{11}$ Amelanotic malignant melanoma without a radial growth phase can sometimes be confused with epulis or squamous cell carcinoma with clinical similarity. ${ }^{12}$

The primary method of treating oral malignant melanoma is extensive surgical resection. In reviewing the outcome of primary mucosal melanomas treated only with radiotherapy, $44 \%$ of patients survived for a mean period of 4.5 years. Although these results seem encouraging, radiation can often be used as an additional form of treatment after surgery or failure of previous management. If there is no metastasis after examinations and investigations, it will be the preferred option for surgical treatment. ${ }^{13}$

Despite drug therapy (dacarbazine), therapeutic radiation and immunotherapy that are used in the treatment of cutaneous melanoma, they are debatable for oral malignant melanoma. Tumor vacci- nes are widely used as adjuvant therapy for melanoma. ${ }^{14}$ Based on the literature, the 5-year survival rate is in a wide range of $15 \%$ to $30 \%$, but a large cluster occurs in $10-25 \%$. Generally, patients with metastasis have poor survival rates. ${ }^{15}$

\section{Conclusion}

Most oral melanomas are often asymptomatic and they delay diagnosis until their symptoms appear. Annual evaluation and screening of oral mucosal pigmented lesions are the primary approaches to prevent from oral malignant melanoma. Detailed and careful oral examination, and early biopsy of pigmented or suspected pigmentless masses are important for early diagnosis.

\section{Declaration of patient consent}

The authors certify that they have obtained all appropriate patient consent forms. In the form the patient(s) has/have given his/her/their consent for his/her/their images and other clinical information to be reported in the journal. The patient understands that their names and initials will not be published.

\section{References}

1. Manigandan T, Sagar GV, Amudhan A, Hemalatha VT, Babu NA. Oral malignant melanoma: A case report with review of literature. Contemp Clin Dent 2014;5:415-8.

2. Ashok S, Damera S, Ganesh S, Karri R. Oral malignant melanoma. J Oral Maxillofac Pathol 2020;24(Suppl 1):82-5.

3. Femiano F, Lanza A, Buonaiuto C, Gombos F, Di Spirit F, Cirillo N. Oral malignant melanoma: a review of the literature. Journal of Oral Pathology \& Medicine 2008;37:383-8.

4. Zito PM, Mazzoni T. Cancer, oral melanoma. https://www.ncbi.nlm.nih.gov/books/NBK513276/

5. Thakur SK, Jha S, Singh S, Yadav A. Primary malignant melanoma of maxillary gingiva. Indian J Surg 2014;76:241-2.

6. Ahmadi-Motamayel F, Falsafi P, Baghaei F. Report 
of a rare and aggressive case of oral malignant melanoma. Oral Maxillofac Surg 2013;17:47-51.

7. Reddy B, Sridhar GR, Anuradha CH, Chandrasekhar P, Lingamaneni KP. Malignant melanoma of the mandibular gingiva: A rare occurrence. Indian J Dent Res 2010;21:302-5.

8. Rathore RS, Phulari RG, Vasavada DG, Patel DK. A rare and extensive case of oral malignant melanoma involving mandibular gingiva. J Clin Diagn Res 2016;10:11-2.

9. Rani GS, Kumar TV, Kolasani B, Begum MR, Priya Srinivasan A. Primary malignant melanoma of maxilla: report of a case with discussion. Case Rep Dent 2014;2014:624306.

10. Tchernev G, Lotti T, Wollina U. Palatal melanoma: "The Silent Killer". Open Access Maced J Med Sci 2018;6:364-6.

11. Munde A, Juvekar MV, Karle RR, Wankhede P. Malignant melanoma of the oral cavity: Report of two cases. Contemp Clin Dent 2014;5:227-30.

12. Kim BJ, Kim H, Chang Y, Kwon K, Cho S. Primary amelanotic melanoma of the mandibular gingiva Arch Craniofac Surg 2020;21:132-6.

13. Ebenezer J. Malignant melanoma of the oral cavity. Indian J Dent Res 2006;17:94.

14. Deyhimi P, Razavi SM, Shahnaseri S, Khalesi S, Homayoni S, Tavakoli P. Rare and extensive malignant melanoma of the oral cavity: Report of two cases. J Dent (Shiraz) 2017;18:227-33.

15. Panda S, Dash S, Besra K, Samantaray S, Pathy PC, Rout N. Clinicopathological study of malignant melanoma in a regional cancer center. Indian J Cancer 2018;55:292-6. 